\title{
Women in Demography in Canada: The 1940's to the Late 1960's
}

\author{
Sylvia T. Wargon \\ Statistics Canada \\ Ottawwa, Ontario, Canada
}

\begin{abstract}
This paper summarizes some of the activities and work of a number of women who were involved in demography in Canada in the 1940's, the 1950's and the 1960's. Selection was based simply on documented work, or employment experience, or both, with a central focus on demographic and population concerns. Of those included, only a few were "super stars". Some made only "one-time" contributions, rather than devoting life-time careers to demography. All are included on the strength of certain activities, initiatives or accomplishments that laid foundations on which others were subsequently able to build.
\end{abstract}

\section{Résumé}

Ce document résume certaines des activités et le travail d'un certain nombre de femmes qui furent impliquées en démographie au Canada au cours des années 1940, 1950 et 1960. La sélection se basait simplement sur đes documents de référence, sur l'expérience de travail ou sur les deux, en mettant l'accent sur la démographie et sur la population en tant que telles. Parmi ces femmes, on ne retrouve que quelques «grandes vedettes». Certaines ne firent qu'une seule contribution plutôt que de consacrer toute leur vie à la đémographie. Elles sont toutes incluses en vertu de certaines activitées, d'initiatives et d'accomplissements qui ont pavé le chemin pour les autres qui ont suivi.

Key Words: Women in Demography, Canada, 1940's to late 1960's.

\section{Why Examine Women in Demography?}

These days efforts are being made to "reconstruct" or "complete" the historical picture of events (whether it be the history of art, literature, science, music, etc.) by filling - in the "missing" story of women's contributions. It has been said that this is one of the legitimate functions of women's studies ${ }^{1}$. The following presentation summarizes some of the activities and work of a number of women who were involved in demography in Canada in the 1940's, 1950's, and 1960's. The criterion for inclusion was simply documented work or employment experience (or both), with a central focus on demographic and population concerns. ${ }^{2}$ Few of these women were outstanding, that is "super stars". Some made 
only "one-time" contributions, rather than devoting life-time careers to demographic work. All are included on the strength of certain activities, initiatives, or accomplishments that laid foundations upon which others were subsequently able to build.

\section{What is demography in the context of this presentation?}

In this presentation, demography is understood to include both formal demography, or demographic analysis, and population studies, sometimes referred to as social demography. ${ }^{3}$ Quite apart from the academic issue of how the discipline is defined, it soon becomes obvious that in the context of this study, demography must be considered in its broadest sense. This is because most of the women who "worked" in demography in Canada from the 1940's to the late 1960's were trained and had expertise (either through education, experience or a combination of both) in a variety of different fields such as sociology, statistics, mathematics, etc. but especially in economics. Indeed, five of the women whose work is noted here, Timlin, Macleod, Salisbury, Levitt and Anderson were formally trained, that is, obtained degrees in economics.

Setting the Scene: Canada the Nation, Demography, and the Position of Women in the Period 1900 to the Late 1960's.

It is helpful to set the scene by sketching, in broad strokes, the picture of "what things were like" in Canada in the period from 1900 to the end of the 1960 's, focussing on key aspects such as Canada the nation, the teaching and practice of demography and the status of women.

\section{Canada the Nation}

Consider the fact that the period examined predates for the most part, the full effects of the quiet revolution (la révolution tranquille) in Quebec, the royal commission on bilingualism and biculturalism, the establishment of Canada's "official" bilingualism policy, and the royal commission on the status of women, to mention only a few events. It is the Canada of the traditional "two solitudes". French-speaking Canada in this period was essentially Quebec and parts of New Brunswick (the University of Moncton in New Brunswick, the largest French-speaking university outside 
of Quebec did not become established until 1963). English speaking Canada consisted of all the provinces outside of Quebec, excluding francophone New Brunswick. However, it also included McGill University and some other English language universities in Montreal and elsewhere in Quebec.

Before and even during the quiet revolution of the 1960's, it was quite possible to grow up, study, earn higher degrees, and indeed live one's entire life in Quebec, and particularly in Montreal, using only the English language. Because of the way in which life in Montreal was structured and organized at that time, the ability to understand and to speak French was not a necessity. McGill University was founded as an anglophone institution in Montreal in the heart of francophone Quebec, and so remains even today. However, there and in other originally anglophone schools in Montreal, courses and training in French were gradually made available in the 1960 's, as for example, at Sir George Williams University, later combined with Loyola to become Concordia University.

\section{Demography in Canada}

In the first half of the twentieth century, there were no formal teaching programs in demography, or in population studies offered as part of the curricula of Canadian universities. But this was not unusual. In fact, in the 1920's in Great Britain, the birthplace of demography, the situation was essentially the same. As one writer noted of this period: "There was no post in any British university devoted exclusively to demography or to population studies, and there were few scholars whose primary interest lay in this field" (Grebenik, 1959, pp. 193-194). In Canada; this situation remained essentially the same until the beginning of the 1950's. Enid Charles gave a population course at Carleton College (later Carleton University) in the mid-1940's, as did Betty Macleod also at McMaster University during 1948-50. Norman Ryder gave a course in population in the (almost-born) Department of Sociology, University of Toronto in 1951-52. Dennis Wrong who succeeded him there also gave a course on the subject in 1955-56. But these were all short-lived arrangements. The teaching of demography in a structured way began in 1950 in Quebec in Laval's Department of Sociology and anthropology. In 1954, Jacques Henripin began teaching the subject in the Department of Economics at the University of Montreal. In 1964-65, at this university, the Department of Demography was -established with Henripin as director. . In English 
Canada, the study of population became a part of the curricula of the sociology departments at the universities of Alberta and Western Ontario in the early 1960 's.

However, during the early part of the period 1900 to the late 1960 's, and especially from the 1920's on, there were individual academics, mostly in Ontario and Quebec universities in departments of economics, history, sociology, etc. who pursued research in population or on populationrelated subjects and issues, and who must have imparted this interest to certain students. The pre-eminent example in this early period was $\mathbf{W}$. Burton Hurd, an economist, who taught first at Brandon College in Manitoba and later in the Department of Political Economy at McMaster University. Hurd has been rightly referred to by Norman Ryder as the only demographer in the university setting in Canada in the 1940's (Ryder, 1988), although Ryder points out that Hurd never gave a course in population at McMaster (Ryder, 1991). Nevertheless, he did encourage Macleod and Ryder to go on to study demography. Since Hurd was already publishing demographic materials in Canada as of the late 1920's, students must have become aware of his population interests in this way, as well as in their personal contacts with him.

Before 1950, demographic activities were on-going in some federal government agencies, particularly in the bureau (then known as the Dominion Bureau of Statistics, or DBS), and also in the Quebec provincial statistical agency, BSQ, founded some years before the establishment of DBS in 1918. At DBS, demographic research and publication were mainly associated with the census and vital statistics programs. Burton Hurd while at Brandon College, and later at McMaster, prepared census monographs on population subjects in connection with the 1921, 1931 and 1941 censuses. In 1936, Nathan Keyfitz arrived at the bureau, joining Murdoch MacLean, Alan LeNeveu, William Tracey and others, who were involved in the census and vital statistics programs, and in related research documented in monographs, articles, parts of census volumes and scholarly papers based on the two main sources of "official" population statistics in Canada.

Outside of the universities and government agencies in the 1930's, Kuczynski (who was not a Canadian) and Langlois in Quebec published important work on Canada and Quebec, respectively (Kuczynski, 1930; Langlois, 1934). In the same period, Rosenberg began his studies of the demographic, social and economic characteristics of the Jews in Canada 
(Rosenberg, 1939). Similar work on other ethnic groups was pursued in this and subsequent decades, mainly in the private sector (Stone and Kokich, 1966).

\section{Women in Canada}

During the first sixty years in Canada, there was no such thing as the feminist movement, womens' liberation, and all the consciousness-raising about women's professional and economic status. In the earliest years of the twentieth century, there were the suffragettes, those early pioneers who strove to get certain rights for women, especially the right to vote. The right of women to vote in federal elections in Canada was granted on May 24, 1918, and this was followed in most provinces by the right to vote in provincial elections. There were only two "hold out" provinces, Prince Edward Island and Quebec. In P.E.I., the right to vote in provincial elections came in 1922. But it took until 1940 for the right of women to vote in Quebec to be won, and this occurred amidst considerable controversy - there was not much sympathy for feminist initiatives in that province (Stoddart, 1973; Johnson, 1971).

Then of course the Second World War saw women enter the labour force in an unprecedented way. But although this eventually meant a great and irreversible change in the behaviour and modes of thinking vis-à-vis women in gainful employment, these new ideas and ideals were to a degree "put on hold" after the Second World War and during the 1950's (Archibald, 1970, p. 16). This author notes that married women left their jobs before 1947, that is, before the veterans returned home and even before the public service enacted certain rules restricting married women's participation in the labour force. Young men and women retreated to the "breadwinner" style family form, to have their "modal" family of two children in a home in the suburbs. All this of course was immortalized in Betty Friedan's "Feminine Mystique" (1963). Essentially, these are the years before the feminist movement really "made a difference" in Canadian and Quebec life. And in Quebec the women's movement was slower to materialize than in the rest of Canada. This was because of the unique history of that province, and an inherent conservatism, the result of traditional Catholicism, and the influence of the church (Rocher, 1962). Accordingly in Quebec, women did not become rightful persons under the law until 1964! Also during the 1960's, the "quiet revolution" took 
precedence, consuming everyone's energies: feminism in Quebec had to wait.

Of course, it is important to remember that as early as the 1920's there were some well known feminists in Quebec like Therèse Casgrain, and later, Solange Chaput-Rolland, who were formidable role models, women of action and determination who accomplished a great deal on behalf of women in their province. And in the social sciences after the 1950's there were sociologists like Colette Carisse, Danielle Juteau (Lee), Alice Parizeau, and others. ${ }^{4}$ But ironically, although demography began to be "formally" taught about a decade earlier in Quebec than in English Canada, French-Canadian, francophone women only surfaced visibly as "career" demographers in the universities and government agencies, in the 1970's. Evelyne Lapierre (later Lapierre-Adamcyk) and Yolande Lavoie were both awarded the Master's degree from the Department of Demography, University of Montreal in 1969. The former began her career working as a demographer in Ottawa in the closing years of the 1960's, after completing the required MA course work. Yolande Lavoie remained in Quebec, joined the Department of Demography as a research assistant in 1968, and began publishing in 1970. The accomplishments of francophone women in demography in the contemporary period is the subject of a sequel to this article. Suffice to say, in the 1970's women in Quebec more than made up for their late start with training obtained in the mid and late 1960's and early 1970's in the University of Montreal's Department of Demography, 5 and we all know what has since been accomplished in the last twenty years by Evelyne Lapierre-Adamcyk, Yolande Lavoie, Muriel Roy, Jeanine Perreault, Nicole Marcil-Gratton, Diane Vanasse and others, and by the upcoming younger generations of Quebec women demographers, but that is another story.

The Professional and Economic Status of Men and Women in Demography and Related Fields in Canada in the 1940's. Some Non-empirical Observations.

Despite the increased labour force participation of women with social science training in the 1940's and 1950's, there is little empirical information readily available on the job classification and pay levels of men and women who were working in demography and related fields. There was little discussion, as there is today, about the "wage gap" in the earnings of men and women. The concepts of "equal opportunity", "employment 
equity" and "pay equity" had not yet been coined. A few studies were published sporadically in the late 1950's and early 1960's (Canada, 1959, 1964a). It was only in the late 1960's that a distinct body of relevant literature began to appear from DBS and elsewhere (Judek, 1968; Ostry, 1968; Allingham, 1967; Allingham and Spencer, 1968; Archibald, 1970; Robson and Lapointe, 1971). The establishment in 1967 of the Royal Commission on the Status of Women undoubtedly encouraged some of these studies.

Given the lack of empirical information for the 1940's, it is interesting and informative to consider some non-empirical observations by social scientists who worked in demography and related fields in those years. Speaking of the federal government service, one eye-witness recounts the following:

There was tremendous expansion during and immediately after the war. Because most of the men were in the services until (19)46, a lot of women were hired in junior professional and senior clerical positions. New university graduates were all brought in at the senior clerical levels (both men and women). The servicemen, when they were demobbed, either went back to university to complete their interrupted education or to take graduate degrees on their veterans' education allowances. By the mid to late forties the middle and junior levels of research workers in economics and statistics were mostly women. Those in supervisory capacities were either economists or Statisticians I or II. Those just "working at it" were classified as clerks....

...There were quite a lot of women in professional and quasiprofessional jobs in government economic and statistical research in the mid and late forties. The dearth of women involved in demography probably merely reflected the general lack of interest in the subject among academics and politicians. The revolutionary changes in the Canadian economy during the war captured the attention of most of these people and riveted attention on more short-term aspects of change....(Salisbury, 1991).

Of more immediate interest in the context of the job levels of social scientists in this period, particularly as they compared for women and men, are the early experiences of Zenon Sametz and Betty Macleod. These two 
came to Ottawa in the mid 1940's after graduation from university to work for the federal government, and their subsequent careers involved them in demographic work.

Zenon Sametz had earned a B.A. in Sociology followed with an M.A. in Political Economy at the University of Toronto in the early 1940's. In 1944, Sametz was invalided out of the army, and since the Second World War was still on, he could not take advantage of a scholarship he had won for Ph.D. studies at Columbia University. Selective Service told him to go and find employment with the federal government in Ottawa:

....they had a Clerk Grade 3 opening working on the 1941 Census analysis, and I was immediately hired to work for Nathan Keyfitz. It was a huge room, converted from the former stable of either E.B. Eddy or the lumber baron who resided where the Prime Minister's residence is now. The IBM machines clattered away. While I was off on the side compiling their data, Nathan was pretty busy supervising, so I had little chance of recognizing the qualities of this world-class demographer before I was suddenly transferred three days later into the new National Income Division. This was probably the shortest career in demography that anyone ever had....

The National Income Division was in the Temporary Building across Sussex Street, where the Ottawa City Hall now stands. This was exciting stuff, as the Keynesian economists who were setting fiscal policy needed the data and DBS was giving it a priority. I was assigned to work on consumer income and expenditure. ....However my work on National Income was almost equally short, as I received a call from Dr. O.J. Firestone, offering me a job as Economist Grade 1 in the Department of Reconstruction which was now being formed.

When I notified DBS, I was summoned to see Mr. H. Marshall, then Assistant Dominion Statistician, who offered me a promotion to Statistician Grade 1 to stay at DBS. It was quite a session, as I was committed to go and asked why an MA. had been hired as a Clerk Grade 3, when there was a STAT I opening. For a few years $I$ was cautious in my continuing relations with DBS, but I think I had made a lasting impression....(Sametz, 1990). 
It is interesting to compare this story with the details of Betty Macleod's job experiences in Ottawa at just about the same time in the 1940's, perhaps one year later. Macleod graduated in 1945 from McMaster, having earned a B.A. in Arts with a specialization in economics. She came to work for the Wartime Prices and Trade Board in Ottawa during 194546. Eventually the entire project and Macleod were transferred to DBS. Originally classified as a statistical clerk Grade 3 , she was upgraded to the next level, statistical clerk Grade 4 after this move to DBS. In 1947-48, after completing an M.A. in economics at Duke University in the United States, where she studied with J.J. Spengler, McLeod returned to Canada and worked at DBS in housing statistics, sampling design, consumer surveys and related work. She was classified in this job as a Statistician I - the job level that Sametz had "discussed" with Herbert Marshall in $1944 .^{6}$ In the early years, certain clerical and junior statistical positions at DBS enjoyed "professional" status and were ranked at the "chief" level. Depending on the classification, and on whether the incumbents had university degrees, these positions were rewarded accordingly (Worton, 1990).

Therefore, in the mid-1940's, both Sametz and Macleod had had very similar "job classification" experiences. The only difference was in the individual reactions to their respective situations. Macleod probably never dreamed of disputing her job level. In those days, most women simply did not challenge authority. Indeed, Macleod considered herself fortunate and notes that she was "awfully lucky in attracting sponsors throughout my career." These sponsors included Burton Hurd, J.J. Spengler, Herbert Marshall and others (Macleod, 1991). Undoubtedly it was her ability and initiative, as well as her acquaintance with demography (a subject then not widely known or studied) that earned her the support of these "mentors", all of whom were men. In this connection, the work of Menard and Rossiter on the growth of science, and conditions of employment of men and women in the early stages of such growth, is most pertinent and worth exploring (Rossiter, 1976).

\section{Women in Demography and Related Fields Elsewhere}

Were there women in other countries around the world working in population statistics and related fields in this period? In the 1930's, Enid Charles had already established a reputation - as a population statistics 
specialist in England. In the United States, following Margaret Sanger, who in the 1920's was not only President of the American Birth Control League, but was also involved in population matters at the international level, a number of women became known in their own right in the population field. These included Margaret Jarman Hagood, Dorothy Swaine Thomas, Hope Eldridge and Irene Taeuber. Soon Evelyn Kitagawa, Ann Miller and Jeanne Clare Ridley appeared on the scene, followed by Judith Blake. Also in the United States, Mindel Sheps, who originally trained in medicine in Canada where she was born, pursued a successful teaching and research career during the 1950's and 1960's in the mathematical aspects of population. She was joined in this work in 1966 by Jane Menken. Monica Boyd began publishing in the late 1960's in the U.S. before coming to Canada. In Italy, in the academic year 1957-58, Mme. Nora Federici gave courses in demography at the newly created Institute of Demography, attached to the Faculty of Statistical, Demographic and Actuarial Sciences, University of Rome.

\section{Women in Demography in Canada in the 1940's to the Late 1960's}

\section{Enid Charles}

In 1918, Enid Charles married Lancelot Hogben, a biologist, mathematician, university lecturer, and popularizer of science. He had a high profile, and like his wife, a controversial reputation. According to Nathan Keyfitz, Charles had studied statistics and "...fertility was her subject" (Keyfitz, 1988). Fertility was certainly of interest to her, not only professionally but personally. She and Hogben had four children, all before the early 1930 's. In a Who's Who item, under "Recreation" she listed "maternity"! (Charles, 1939, pp. 563-564). Who said she had no sense of humour?

Charles arrived in Canada in 1941, with her youngest son David, ostensibly to escape war conditions and the "blitz" in England, but apparently there were other personal reasons. ${ }^{7}$ She was already a well-established statistician and demographer with an international if controversial reputation, who had contributed to the published demographic literature of the period (Grebenik, 1959, 1986). Her interest in, and concern about the decline in fertility in the western world had been eloquently expressed in her book "The twilight of parenthood" (1934). In this volume she was not shy about mentioning her status and experience as a mother: 
....With the advantage of being at the same time the mother of four children and a wage-earner in the academic profession, the writer can approach the discussion of a family allowance adequate to act as an incentive to parenthood in the professional class with first hand knowledge of the difficulties....(Charles, 1934, p. 208).

In Canada, Enid Charles worked at DBS, where her position was described as "Census Research Specialist". Her arrival coincided fortuitously with certain important demographic data initiatives undertaken in the bureau in the early 1940's. For the very first time in Canada, questions on nuptiality, fertility and internal migration were included on the 1941 decennial Census questionnaire. The sample fertility enquiries in the 1911 population Census of England and Wales, and in the 1940 U.S. Census of population were examples that motivated Canadian census officials to include these basic demographic questions. And there was a need for these data. The new questions on nuptiality and fertility were introduced in order to obtain data on births for longer periods of time, and in greater depth and detail than was possible with the vital statistics. In addition, three questions on present and former residence were designed to measure the considerable internal movement of population in Canada during the 1930's when international immigration into Canada decreased because of bad times everywhere (Canada, 1945, pp. 32-33).

Although she was at the bureau for a relatively short period of time, Enid Charles helped put Canada "on the world map" from the point of view of demographic research and publication. Her contributions to the growth of demography in Canada were two-fold, relating to demographic analysis and data preparation and documentation. She authored analytical studies on Canadian nuptiality and fertility, which she contributed to standard DBS publications such as the census volumes, the Canada Year Book, etc., and scholarly journals. Charles' 1941 Census monograph, "The changing size of the family in Canada" has generated seminal ideas and methods for subsequent nuptiality and fertility research in Canada and elsewhere. Using the 1941 Canadian Census nuptiality and fertility data, she explored and documented the reasons for the changing birth rate in Canada, and the differentials in childbearing according to religion, residence, education and profession. This monograph also included a summary of the results of the population projections which she prepared with Nathan Keyfitz and Howard Roseborough. Charles also contributed to the development of the 
data she used in analysis (census and vital statistics) and to the documentation of their properties and their reliability. The rich sources of 1941 data on age at marriage, fertility and migration in the 1941 Canadian census volumes are largely attributable to her initiatives and have constituted a very valuable legacy to demographic data and research in Canada. Charles' influence on the bureau's vital statistics program, especially the statistics on divorce, was still being felt in the late 1960's, long after her departure, when attempts to improve their preparation and publication essentially followed the original guidelines she had proposed.

In addition to this work, Charles lectured at Carleton College (later Carleton University). The second, third, fourth and fifth Calendars of Carleton College, Faculty of Public Administration, list Enid Charles as "Lecturer". 8 The course, "Population trends and social policy" which was given in the academic years 1943-44 and 1946-47 but not offered in the other years, is described as follows:

This course is an introduction to Canadian demography and vital statistics. Its objective is to provide the public servant and the student of social science with the basic knowledge of social biology required for effective planning and execution of public policies. Emphasis will be laid on the social implications of longterm trends in human reproductive behaviour and on the population background of post-war problems.

The following topics will be discussed: Growth and distribution of world population; statistical methods of measuring population changes; the declining birthrate; the cultural make-up of the Canadian people; differential fertility; effects of the war on population growth; the future population of Canada and its changing age composition; external and internal migration in relation to national resources and industrial development; metropolitanization; the economics of population change; vital statistics as a yardstick of social welfare; the population background of social security, education and housing; the economics of the family, the cost of a child; the requirements of a biologically planned society.

Dennis (Hume) Wrong describes meeting Enid Charles in the summer of 1945 when he came to DBS as a summer student from the University of Toronto. He speaks of how Nathan Keyfitz: 
....organized a sort of informal class in demography during lunch hour for some of us. We sat on the lawn, above the Ottawa River eating our sandwiches while he talked to us. He introduced Enid Charles and she spoke to us too - a very thin, wrinkled, greyhaired, vigorous woman, always smoking a cigarette....(Wrong, 1974).

This description, including the incessant cigarette smoking, bears out what others have said. From the comments of persons who were at the bureau when Charles was there, it is clear that she gave the appearance of being very confident about her abilities (Goldberg, 1984), but it is also clear that she was not very well liked ${ }^{9}$. More important however, is Keyfitz's recollection that:

....she was a passionate scholar....completely absorbed in her work...(Keyfitz, 1984).

It is futile to speculate about how different the history of demography in Canada might have been had Enid Charles remained at the bureau. She returned to Birmingham in 1947, to join Hogben, but their marriage ended in divorce in 1957. Subsequently she continued to work as a demographer around the globe. She died in Torquay, England in 1972 at the age of 77.

\section{Margaret Fleming}

Also of interest in this period are the activities of Margaret Fleming who worked at DBS (for a period of 43 years) from 1931 to 1974. Fleming's background, training and temperament as well as her status in the bureau were totally different from Enid Charles', yet is obvious that in doing her job and serving her employer, she made lasting contributions to the agency's demographic work.

Fleming joined the bureau as a census clerk in 1931, having taken a general degree in Arts at St. Francis Xavier University in Nova Scotia. She liked mathematics and was very good at figures, so was definitely suited to her job. She worked for Murdoch MacLean, Tracey (author of the 1931 census monograph on fertility and the chief of Vital Statistics in the early 1930's), Keyfitz, Alan LeNeveu, Enid Charles and subsequently, others. It deserves mention here that Margaret Fleming was one of a number of 
women, some of whom had BA degrees, who were employed as clerks in the bureau in these early years. The Misses Fleming, Carmichael, MacGillivray, Richards, Stewart and others were frequently credited as having verified, edited, and even sometimes as authoring materials in DBS volumes. They worked on the General Review census volumes and on the census monographs. They prepared the tables (by hand, of course), verified them, and generally did all the tasks associated with the preparation and publication of descriptive, tabular and analytical materials. In addition, Fleming contributed to the text of the 1931 monograph on fertility by Tracey (after the latter's untimely death), and also served as editor of the analytical chapters making up the 1941 and 1961 Census General Review volumes. Fleming did a lot of work for and with Keyfitz, whom she admired and described as "easy to work for" (Fleming, 1988). She assisted him in his life-table and labour force survey projects, and in answering the requests for information he received, often from senior government officials. The story of how she became identified with the DBS population estimates program is revealing. Keyfitz devised a methodology in the mid-1940's, improving on earlier efforts, and assigned Fleming the task of doing the calculations, instructing her in the details of how to use and adjust the necessary data. Henceforth, these population estimates became a part of the bureau's official publication program and were prepared and released by DBS, first under A.H. LeNeveu and then under Margaret Fleming (Canada, 1987). She continued to prepare the population estimates until her retirement in 1974.

During the 1960's in response to the need to document the estimates work, she authored and co-authored a number of technical papers on aspects of this work (LeNeveu and Fleming, 1965; Fleming, 1967; Nagnur and Fleming, 1969; Fleming and Nagnur, 1970). These papers were of considerable help to the professional demographers assigned to do the estimates work. There is an amusing story of how, during the late 1960's or early 1970 's, an attempt was made to computerize these estimates. The late Dhruva Nagnur was assigned the task. He related that the attempt failed completely: it was impossible to computerize the estimates. They were simply not as good as when Margaret (Fleming) did them. "It's in her blood..." Nagnur would say, shaking his head as if there was something rather mysterious about the way she was able to do this work in a manner superior to the computer. 
Mabel F. Timlin ${ }^{10}$

Mabel Timlin was one of those people who came to economics and to academic life in Canada relatively late, and only after an interesting journey.

....Her career, as a scholar and university teacher was a most remarkable one, both in the way it was undertaken....and in the way it was pursued: with dedication of an uncommon kind....(Spafford, 1977).

Born in Wisconsin, she obtained two years of teacher training after graduation from high school and taught in elementary schools. After both parents died in 1916, she immigrated to Saskatchewan. There she taught typing and shorthand, among other things, until 1921, when she became a secretary in one of the departments of the University of Saskatchewan. Working full-time as a secretary, Timlin completed the requirements for a bachelors's degree, taking one course at a time. In 1929, she became director of the University of Saskatchewan's program of correspondence courses, and assumed personal responsibility for the extramural courses in economics. In 1932, in a second try at studying economics, she became a doctoral candidate in economics at the University of Washington. In 1935, at the age of 43, Mabel Timlin was given her first regular academic appointment as instructor in economics. She continued to be director of correspondence courses until 1942.

Timlin had a successful career as an economist, teaching, publishing (in both American and Canadian professional journals), and taking part in the activities of various national and international professional associations in which she held office. First and foremost an economist, Timlin was essentially interested in economic theory, and this was the area in which she made her greatest contributions. She was an expert in Keynesian economics (the subject of her doctoral dissertation). During her tenure, and probably because of her presence there, the University of Saskatchewan's Department of Economics was second in reputation only to that of the University of Toronto, where Innis reigned supreme. Like Hurd, she developed and nurtured students of talent, encouraging the ones she considered superior to do graduate studies in economics (Kenneth Buckley was one of these students). 
In the summer of 1949, with an academic reputation firmly established, Timlin accepted an invitation from the federal government to prepare a study of Canada's "absorptive capacity", that is, on the economic aspects and repercussions of immigration. The report of this study was the published volume "Does Canada Need More People?" (Timlin, 1951). Timlin concluded, after presenting definitions, and the possible results of immigration implied by population projections produced by DBS in the 1940 's, that a larger population for Canada should mean higher real incomes for Canadian citizens. She further proposed:

....freer migration than we have known for the past twenty years, and trade policies favouring continuation of large-scale movements of goods in international trade....(Timlin, 1951, p. 123).

In presenting this conclusion, Timlin noted the need for more research, particularly for "....extended demographic research" (Timlin, 1951, p. 123). It is this monograph which has linked her name with demography in Canada. Widely read and cited by those working in the field of immigration, her book is still used as a reference work by scholars and students whose interest is mainly in immigration and in population policy. Brilliant and versatile, Timlin continued along other paths in the 1960's.

\section{Betty Macleod}

Betty Belle (Robinson) Macleod relates how in 1942 when she came to enrol in studies at McMaster University, her intention was to register in sociology. W. Burton Hurd, who interviewed her, presumably guessed her potential and persuaded her to enrol in economics. It was through this initial contact with Hurd and subsequently in the late 1940's (after earning an M.A. in economics from Duke University, where she studied with Joseph J. Spengler), that Betty Macleod became one of the first teaching and practising demographers in English Canada.

In 1948, at Hurd's invitation, Macleod joined the Department of Political Economy at McMaster University, as a Lecturer and Research Assistant during 1948-50. Macleod has indicated that her studies with Spengler and her familiarity with the Canadian statistics and government personnel gained during her stay at DBS very likely influenced Hurd in hiring her (Macleod, 1991). During 1948-49, and then again in 1949-50, she gave a 
lecture course in Population. (Hurd was listed as giving this course in the McMaster calendar. Macleod could not be listed since she was not yet an Assistant Professor. Apparently this was a frequent practice at universities in those days). Other duties included the direction of undergraduate theses, some treating demographic themes, leading discussion groups on the principles of economics, and supervising workshops in statistics for students learning how to use calculators in connection with their assignments. The workshops were held in Canada's first research lab, McMaster's Economics Research Laboratory, which had been established by Hurd. In 1949, she also organized and participated in a symposium at McMaster on "Population growth and immigration into Canada". In this period her research was primarily on immigration into Canada.

In 1950, Macleod accepted Spengler's offer of a Duke University fellowship to pursue doctoral studies in economics, specializing in population and related areas. She returned to Ottawa in 1952 to work and commence research on her doctoral thesis. In January, 1953, Macleod began working at the United Nations in New York, mainly in the field of fertility analysis under the direction of Halvor Gille, where she was fortunate also to meet other world-class demographers working there, including P.K. Whelpton.

Macleod subsequently returned to Canada, residing in Montreal. There she joined Sir George Williams University where as Assistant Professor during 1964-66, taught courses in economics and demography, including a course on Population Problems co-sponsored by the Departments of Sociology and Economics. In 1966, now living in Toronto, she joined the Ontario Institute for Studies in Education (OISE) in the Department of Educational Planning as a Lecturer. In 1967, with her Ph.D. completed, Macleod she became an Assistant Professor with a cross-appointment to the University of Toronto's School of Graduate Studies (1967-69).

Macleod was recruited to OISE primarily because of her background in demography, and the need to project the school-aged population for Ontario on a basis consistent with educational planning areas. Because trends in fertility were vital to these considerations, several projects on these trends and regional differentials throughout the province were prepared and published. Also investigated were migration and rates of urban growth as well as manpower and occupational patterns. She gave courses in Demographic Methods for Educational Planning, Analysis of Fertility, and Advanced Demographic Analysis, among others: - In this- 
period, she also served as a consultant in demography to a study on mental health by the Clarke Institute of Psychiatry, directed a study on Ontario's population trends, and in 1969 organized a conference on the implications of demographic factors for educational planning and research, later documented in a publication (1970). In the 1970's Macleod participated in the establishment of the Canadian Population Society in which she held office. Later, still at OISE she joined the Department of Adult Education where, among other assignments she offered courses in gerontology, emphasizing the demographic and economic aspects and their implications for continuing education. Macleod retired in 1985.

Betty Macleod's accomplishments were considerable and commendable particularly in view of the situation at McMaster in the 1940's which has been described as "sexist" (Ryder, 1988). According to one of the first investigations of the status of women in academe conducted at McMaster in 1971, a good twenty years after Macleod began her career there, this atmosphere apparently persisted! (McDonald and Lenglet, 1973, p. 240).

\section{Helen Salisbury}

Helen (Madge) Salisbury graduated from McMaster University in 1946 with an undergraduate degree in economics. Also a student of Hurd's, (she took economics classes with Macleod), she admired him and remembers his abilities as a teacher, and his interest in population. But she herself was not particularly drawn to demography.

From 1946 to 1956, Salisbury worked for the federal Department of Labour in Ottawa as a statistician in its Research and Statistics Branch. There, among other things, she estimated regional labour force participation rates for post-censal periods. This involved using DBS provincial population estimates by age, and adjusting the census data for estimated growth in labour force and employment, using any figures available (e.g., employment and payroll data, UIC data, etc.). This work put her in contact with DBS personnel knowledgeable about projections.

Salisbury's interest in demography was stimulated when she went to work for the Ontario government in Toronto in 1956. At that time, she was attached to the Department of Economics in the Ministry of Finance (subsequently, with the Department of Economic Development, then with Treasury and Revenue, and eventually with Treasury and Economics). 
The concern in Ontario at this time when Leslie Frost was provincial premier was largely "....to get a handle on spending requirements for education, health and municipal grants...." (Salisbury, 1991). Thus, the interest that developed there in the preparation of population projections was motivated by financial and practical concerns. In any case, the demographic activities in the finance ministry of the Ontario government became, and remained Salisbury's responsibility from 1956 to about 1980 (Salisbury, 1991).

Salisbury became involved in the production of projections of population for Ontario apparently over Yoshiko Kasahara's protests that provincial projections were not feasible at that time because of lack of appropriate data on migration. In spite of this warning Salisbury and her group went ahead with these projections in the late 1950's, eventually progressing in the 1960's to the use of computers. She concedes that this early work was rather "rough", but this did not deter her:

....Because of the difficulties in programming those first phase computers, we had to make some very simplistic....assumptions. It made little difference, as we grossly underestimated the changes in birth rates and any sophistication in techniques would not have overcome that basic error in judgement. The projections did, however, awaken the government to coming problems in providing hospitals, schools and post-secondary education facilities and moved them to change their policies and priorities. The projections were surprisingly accurate for the medium to the short term (Salisbury, 1991).

Although involved in this manner in demographic activities, Salisbury always considered herself primarily a political economist:

....I have been classified at various times as a statistician.....an economist..... policy advisor and a manager....I always felt that my job was to obtain the best information and to give my political bosses a good background for decision making, be it in population changes, income distribution, health care costs and facilities, economic outlook, etc....(Salisbury, 1991).

Salisbury was one in a series of "managers" in the Department of Economics and its later incarnations in the financial or treasury arm of the Ontario government. She initiated and developed demographic work that 
served as the basis for making policy decisions. Subsequent research by her group was documented in the late 1960's by Kogler, an officer Salisbury hired. Much of the early work for which she was responsible was "....for internal policy purposes and was never published" (Salisbury, 1991).

\section{Yoshiko Kasahara}

Originally a student, and then a teacher of English language and literature in her native Japan, Dr. Kasahara (known as Yoshi to friends and colleagues) translated into Japanese, Harold Laski's "Reflections on the revolution of our time". In 1950, she came on an American scholarship to do graduate work at the University of Texas. There she encountered Amos Hawley and his ecological studies, and completed an M.A. degree in sociology. Subsequently, and again on a scholarship, she continued her studies at the University of Michigan where she was awarded an M.A. in mathematics, and in 1958 a Ph.D. in sociology. In the course of her studies in the United States she met Irene Taeuber and became her protegée. Yoshi was extremely proud of this association with one of the leading demographers of the time. In 1956, Yoshi joined DBS, and after a brief association with the census division she became a member of the central research and development staff attached to Simon Goldberg's office. Kasahara's impact on early Canadian demography is easily surmised if we look at the situation of demographic research and activities in the bureau in the 1950's.

At a time when demography was relatively undeveloped, and demographers were in short supply in Canada and around the world, the work of the bureau in the population field was very much in evidence both at home and abroad, due to the activities of a handful of individuals: Coats, Charles and Keyfitz. In Canada, the decade of the 1950's was ushered in by the publication of Keyfitz's comprehensive article, "The Growth of Canadian Population" (Keyfitz, 1950). In the same year, Keyfitz was elected for membership to the International Union for the Scientific Study of Population (IUSSP), and as a DBS officer, he continued to give presentations at conferences and publish the results of this research. However, the development of demographic data and research at the bureau was somewhat slowed in this decade compared with the 1940's. Enid Charles had left Canada in 1947. Although Nathan Keyfitz was still at the bureau, involved as always in numerous statistical and demographic activities, he began to travel abroad in the 1950's on consultation work, and 
was therefore not in Ottawa on a regular basis. The 1951 Canadian Census questionnaire did not include questions on nuptiality, fertility and migration. Although this was attributed to "post war conditions", it was in sharp contrast to the 1941 Census when these questions were included on the questionnaire at a time when the country was at war! Norman Ryder was briefly at the bureau again in 1950 (he had been there in the late 1940 's), but had left for the University of Toronto in 1951, where he spent the next three years before leaving for the United States in 1954. However, Kasahara arrived at the bureau in 1956 . With her work and that of Keyfitz (until his departure in 1959), and A.H. LeNeveu, a bureau line manager in the Census division, demographic research at DBS managed to survive in the 1950's (Kasahara and LeNeveu, 1958).

In the early 1960's, demography at the bureau was back on track. Questions on age at marriage, fertility and migration were again included on the 1961 Census questionnaire, as in 1941. Planning and preparation of the 1961 questions on fertility, migration and income, included together on a "confidential" sample form, was the combined work of Kasahara, contributing the demographic expertise, and Jenny Podoluk, a bureau income specialist providing the economic expertise. In spite of certain problems with the processing and release of the 1961 demographic data, and exacerbated by Kasahara's untimely death in 1966, the considerable 1961 Census demographic data owe their existence to her efforts. ${ }^{11}$

Kasahara was also originally the designated author of the 1961 Census monograph on migration in Canada, a project undertaken by others after her death. Two 1961 monograph authors who subsequently prepared volumes on migration in Canada acknowledged her special contributions: an original outline that determined the contents of the two volumes, numerous tabulations of migration data that she had designed, and the fact that she made the 1961 Census demographic data a reality (Stone 1969; George, 1970). In addition, in a career spanning ten years at the bureau, Kasahara published a number of papers on Canadian demographic subjects such as internal migration, urbanization, population growth, family migration, etc., and gave presentations in Canada and at international conferences on these subjects. In the first half of the 1960's she was responsible for the preparation of the bureau's population projections (Kasahara et al., 1964). A review of the early projections work in Canada notes that: 
Judging from the methodology used and the rationale of the assumptions involved, Kasahara's projections are by far the best of the projections under review. (George, 1967)

Yoshiko Kasahara passed away on December 6, 1966, at the age of 54, and "...her death marked the premature end of a brilliant career" (Goldberg, 1967).

\section{Kari Levitt}

In 1960, the Atlantic Provinces Economic Council (APEC) published a study commissioned by the Atlantic Provinces Research Board on "Population movements in the Atlantic provinces" (Levitt, 1960). The author, Kari Levitt, was trained as an economist in England at the London School of Economics (B.A., 1947), and later at the University of Toronto (M.A., 1958). How she came to examine and analyze the net migration of population out of the Atlantic provinces, and wherever possible, internal population movements within the region, is best explained in her own words:

I had no training in demography except insofar as LSE courses in statistics included also the statistics of population (birth, fertility, mortality, net reproduction rates, etc.)...

In the late 1950 's, when I was a graduate student at the University of Toronto, I became interested in the economics of underdevelopment of regions/countries. My professor at that time was B.S. Keirstead who had strong connections with the Maritimes, particularly in Fredericton. He put me in contact with APEC....

I was employed in Fredericton, N.B. in a summer job by the Atlantic Provinces Economic Council in 1960. I was asked to make estimates of net migration out of each of the Atlantic provinces for 10-year periods (working with decennial census data). From available literature I devised the methodology used in my study. It is possible that I asked Nathan Keyfitz for advice.... 
At this time there was a hot and heavy policy debate concerning development policy for the Maritimes. There was an opinion that people should be assisted to migrate out of poorer regions to Central Canada. This argument was based on "comparative advantage" of Central Canada, and it was argued that outmigration would raise GNP per head of the (fewer) remaining heads. The Government of Canada favoured assisted outmigration.

The counter-view, supported by APEC and indeed by most people in the Maritimes was that out-migration is detrimental to regional development because it diminishes the rate of family formation (thus negatively affecting housing starts), because it is selective insofar as the younger, more energetic and better educated people are more likely to migrate, and because of created excess capacity of social infrastructure (half-empty schools, etc.) This is the background against which I was asked to analyze net outmigration." (Levitt, 1991)

In the introduction to the 1960 APEC study, Levitt noted that it represented a new area in research. Her bibliography cited Buckley's work as well as a number of studies by DBS personnel. Subsequently she presented the results of the same study at the second CPSA Conference on Statistics in 1961, and this revised version appeared in the volume of conference proceedings (Levitt, 1963). In the early 1960's, Levitt's work complemented and extended the research that Buckley was involved in, and that Kasahara was pursuing at DBS on internal migration in Canada and related subjects. Levitt's 1960 APEC study and its 1963 revision, represented pioneering demographic research on migration in Canada from both a methodological and substantive point of view. Also important was the fact that it shed light on regional disparities in Canada, and attempted to address their policy implications:

....This exercise gains significance if it is regarded as providing information essential to any discussion of the chronically slower rate of economic development in the Atlantic Provinces. Furthermore....the findings of the study have certain policy implications.....whether....to "move people out", or to "move the industry in" (Levitt, 1963). 
At the time that she was doing this work, Levitt was pursuing an academic career. As a professor in McGill University's Department of Economics from the early 1960's to the present, she has continued to be interested in the factors which affect external and internal migration, but essentially as a "development economist" (Levitt, 1991).

\section{Isabel Anderson}

Isabel Anderson studied at the University of Saskatchewan in the early 1960 's, where she obtained undergraduate degrees in mathematics and economics, and subsequently an M.A. in economics. Kenneth Buckley, supervised her Master's thesis on "Components of rural and urban population change in Canada, 1921 to 1960 ". This thesis, completed in 1963, involved:

".... making a new set of estimates of internal migration, focussing not just on inter-provincial migration, but also on the movement of people from farm to non-farm areas in every province of the country. It was done in the spirit of building on the work that....was being done at the DBS....in the spirit of the research....needed....to construct or reconstruct the record, the historical statistics, that could be used to study the process of economic growth and development in....Canada" (Anderson, 1991).

During the years 1964 to 1966, Anderson worked for the Economic Council of Canada in Ottawa, and her thesis provided the basis for the Council publication. "Internal migration in Canada, 1921-1961" (Anderson, 1966). This publication provided the opportunity "....to rework the migration estimates and to continue other parts of the study on internal migration". In the acknowledgements to the 1966 study, Anderson noted its origin in Buckley's studies of Canadian economic growth and internal migration initiated in the Department of Economics and Political Science at the University of Saskatchewan (Anderson, 1966).

In Anderson's subsequent career as a professor of economics, mainly at the University of Saskatchewan where she still teaches today, she has continued to be interested in Canadian economic growth and development, as well as in quantitative methods and international economics. However, she has not pursued her early work in demography. 


\section{Mindel Sheps}

Mindel Sheps obtained her early training (medicine) in Canada, but later pursued demographically-related work in the United States. Her story is briefly recounted here because of its relevance and interest in the context of how women with families pursued professional careers in demography in the period before the 1970's. Perhaps also by including her in this account, we can "claim" her for Canada in some small way.

The "Sheps story" is that of a talented Canadian whose vitality was already making an impression on the Canadian scene when she left the country. Sheps left Canada for the United States in 1947 to accompany her husband, Dr. Cecil Sheps who had a position there. In those days, it was more usual than it is today for women to follow where their husbands' jobs took them. Nevertheless, she did pursue advanced training in the U.S. in biostatistics and mathematical statistics, and became internationally known in both the medical and demographic communities, through her teaching, research work and her prodigious publication record in the field of fertility research. All the while of course, her husband was pursuing his career in the medical field, and publishing, also very successfully. He was always very supportive and applauded his wife's activities and interests. A few details of Sheps' career, provided by her husband, deserve to be told, even though her demographically-related work was pursued in the United States.

Sheps was born in Winnipeg, Manitoba in 1913. She graduated with an M.D. from the University of Manitoba in 1936, interned in Saskatchewan and went on to a residency in Paediatrics in Winnipeg's Children's Hospital. Sheps left for the United States in 1947 along with her husband who had been appointed to the faculty in the School of Public Health, University of North Carolina. In June 1950, she obtained a degree. in public health from the University of North Carolina. According to her husband she also did "....some advanced work in biostatistics and mathematical statistics at the University of North Carolina in Chapel Hill". However, he pointed out that:

...her proficiency in demography was largely self-taught....she had always had an interest in problems of population. This started when she was in general practice in Winnipeg...for a few years in the early 1940 's, with her becoming, inter alia, the physician with the Planned Parenthood organization in that region. From this 
experience, her interest broadened greatly and, in the course of time, focused on mathematical aspects....(Sheps, 1989).

Sheps continued to do post graduate work in biostatistics and mathematical statistics, and went on to a teaching and research career that took her to Boston University Medical School, Harvard Medical School, the Graduate School of Public Health at the University of Pittsburgh, and to the School of Public Health, Columbia University. Her last appointment was as professor in the Department of Biostatistics, School of Public Health, University of North Carolina at Chapel Hill, coinciding with her husband's appointment to the faculty of the School of Medicine. Her more than 70 publications span the years from 1945 to 1972. Unfortunately she died in 1973, much too prematurely, at the age of 60.

Whether or not Sheps could have pursued a career in fertility research in Canada similar to the one she had in the United States is an academic question. She left Canada to accompany her husband - and in this indirect way became a part of the "brain drain" from Canada to the U.S. in the 1940 's. ${ }^{12}$ Her career in the United States took the pattern it did at various institutions because, as was the custom at that time, she accompanied her husband as he moved to various positions. But obviously she was intent upon, and able to follow her own intellectual destiny. On Cecil Sheps' part, he approved, and was very proud of her professional interests, work, and accomplishments. What was it that Therèse Casgrain said in her autobiography....that women would be truly liberated only when men also, were liberated? (Casgrain, 1972). The Sheps couple truly exemplified this important Casgrain "corollary".

\section{Sylvia T. Wargon}

Sylvia Wargon arrived at the DBS in 1962 to work for Alan LeNeveu in the Census division's Social Analysis section. She had a considerable interest in demography particularly in Enid Charles' work, dating from undergraduate studies at Toronto with Hart, Clark and Innis. She was trained in sociology at the University of Toronto (BA, 1946) and the University of Illinois (MA, 1947), where she studied with Florian Znaniecki and E.T. Hiller. This was followed by some years of teaching at the University of Toronto, and later, research experience. As a member of the Social Analysis Section, she prepared analytical chapters (in the form of bulletins) using the 1961 Census demographic data, for the 1961 Census 
General Review volume. With another officer she prepared the bulletin on age and sex composition (Canada, 1964b). She also authored the bulletin on fertility trends (Canada, 1968). During 1963 and 1964 as an assistant to Jacques Henripin, she searched out and prepared background historical materials for the 1961 Census monograph on fertility. In the mid 1960 's as a member of K.J. Krotki's staff, Wargon inherited the task of documenting the details of the processing and treatment of the 1961 Census demographic data. The results of this work appeared in a number of bureau publications (Wargon, 1967a; 1968; Canada, 1970). A detailed inventory of all existing Canadian Census fertility datà was also prepared (Wargon, 1967b). In the late 1960's and the early 1970's her interest turned to the demography of Canadian households and families.

\section{Evelyne Lapierre (-Adamcyk)}

Although her M.A. from the Department of Demography, University of Montreal was granted in 1969, Evelyne Lapierre (later Lapierre-Adamcyk) came to work at the bureau in Ottawa some years earlier. First as a student in the summer of 1967 , and then as of 1968 on contract, she was attached to the Demographic Analysis and Research (DAR) section as a research assistant. In this position, she was engaged in a variety of projects, some of them in collaboration with K.J. Krotki, then Assistant Director of Research, Census Division, and M.V. George, Chief, DAR Section. The results of her work in the late 1960's are available in a Masters thesis "Les variations de la fécondité dans la région de Montréal" (1969a), and in a number of published and unpublished articles and papers. These included an analysis of differential fertility in Canada (with some American comparisons) according to religion, ethnicity and marital status, based on 1961 Census data (Krotki and Lapierre, 1968), recommendations for data on childspacing from the 1971 Census (Lapierre, 1969b), and estimation of net census under-enumeration by age and sex, using demographic analysis techniques (Lapierre, 1970). She also worked on other demographic research projects producing manuscripts in the areas of Canadian fertility (with M.V. George), nuptiality (for the Royal Commission on the Status of Women), and population size (with K.J. Krotki).

The story of how Evelyne Lapierre came to collaborate on a volume with Mindel Sheps, the expatriate Canadian, demonstrates how "small" the world of demography was on the North American continent in the late 
1960's. At that time, Sheps became interested in making some of Louis Henry's fertility research available to the English-speaking public. Through the Population Council, the agency funding her project, Sheps made contact with Evelyne Lapierre, who was then doing some work for the Council, although living and working in Ottawa after completing her training in demography at the University of Montreal. Sheps asked Evelyne Lapierre to help her translate material of Henry's. This was the origin of the volume On the measurement of human fertility. Selected writings of Louis Henry, co-edited by Sheps and Lapierre-Adamcyk (1972).

\section{Conclusion}

In the period of the 1940's to the late 1960's, women who pursued demography professionally in Canada did so (to paraphrase the title of Thérèse Casgrain's autobiography) as "women in a man's world". They "did" demography because they were personally interested or because of circumstances; that is, it was a requirement of their jobs or specific assignments. Some confess that they kept their personal family lives and "problems" hidden lest they give any impression that they might be distracted from their jobs! They did not think of themselves as pioneers nor did they consider their activities as part of their "unfolding careers". They simply did the job at hand as part of "earning a living". Ironically, in one case (Salisbury) this person initially was not particularly interested in demography, even though she had studied with Hurd.

Consider the following: aside from the few "super stars" who were able to chart a course independently, these women had no "role models". Most of them had little or no formal training in demography. Few had mentors to guide and help them along the way, and often toiled in isolation with little support. They worked as social science professionals mainly in the prefeminist era in Canada, before the full impact of the women's liberation movement was felt, and before the consciousness-raising regarding women's status in the work world that began in the 1960's and gathered momentum in the decades that followed. Their efforts helped to get things started in demography in Canada. They deserve our respect, admiration and appreciation, even if it arrives only at this late date in the last decade of the twentieth century. 


\section{Acknowledgements}

The author gratefully acknowledges the information supplied by $I$. Anderson, H. Buckley, M. Fleming, E. Lapierre-Adamcyk, K. Levitt, N. Keyfitz, B. Macleod, J. Perreault, H. Salisbury, C. Sheps, the late Zenon Sametz, N. Ryder, D. Worton and D. Wrong. Thanks also to Carol-Ann French for efficient and timely text production services. Materials for this article were extracted from draft chapters on the history of demography in Canada, in progress. The views expressed here are those of the author and in no way reflect those of. Statistics Canada.

\section{Footnotes}

1. Monique Bégin made this point in a speech given in 1987 when she was Joint Chair of the Institute of Women's Studies, Carleton University and the University of Ottawa.

2. In this period in Canada, there were a number of women social scientists who carved out careers. Early on there was the historian, Hilda Neatby, and sociologists Jean Burnet, Aileen Ross, Eva Younge, and Helen Abell. As of the 1950's, Bernice Levitt worked as an economist for the Ontario government. Later, Colette Carisse, Alice Parizeau and Danielle Juteau (Lee) were career sociologists. The economists Sylvia Ostry and Jenny Podoluk in their work at DBS in the 1960's featured demographic statistics and analyses in monographs and other published work (Ostry and Podoluk, 1966). Nevertheless, the work of these women is not treated here because it was not centrally focussed on demography.

3. According to the classic definition of formal demography or demographic analysis, "Demography is the study of the size, territorial distribution and composition of population, changes therein, and the components of such changes, which may be identified as natality, mortality, territorial movement (migration) and social mobility (change in status)" (Hauser and Duncan, 1959, 2). However, also part of demography is "population studies" sometimes referred to as "social demography", and generally considered to cover the investigation of the relationship between population composition and change, and one or more of a variety of social, economic, cultural, political, biological, geographical or other factors. By definition, population studies has an important interdisciplinary dimension. (See Lorimer, 1959, 187).

4. In the late 1930's, there was mention of a Miss Yvonne Baudry ARRC, Medaille d'honneur Vermeille, attached to the Dominion Bureau of Statistics, Ottawa. She authored a paper on accidental deaths in Canada in 1936 (Baudry, 1938), that was presented and well received in the Section of Vital Statistics and Epidemiology at the twenty-seventh annual meeting of the Canadian Public Health Association, Ottawa, June, 1937. No further information on this person could be found.

5. A portent of things to come is a footnote to an article giving credit to certain students studying demography in 1967-68: "La recherche à la base de cet article a été effectuée dans le cadre du cours DEM-410 (1967-68) au département de démographie de l'université de Montréal. Les méthodes et les résultats sont donc le fruit de la collaboration de tous les participants à-ce cours-- Pour la rédaction; l'auteur s'est 


\section{Sylvia Wargon}

largement inspiré des meilleurs textes qui lui furent remis par les étuđiants, et en particulier de ceux de Mme. Nicole Marcil-Gratton et de Mlle. Yolande Lavoie" (Légaré, 1969).

6. Enid Charles was already, as of $1941-1942$, firmly ensconced at DBS, and her official title was "Census Research Specialist". Her job classification and pay were undoubtedly higher than that of Sametz and Macleod. She was about a generation older than they were, had already earned a doctorate, authored demographic publications enjoying international distribution, and was presumably classified and rewarded accordingly.

7. Information on Charles' date of arrival and length of stay in Canada varies. An exhaustive examination of records currently available would seem to indicate that she arrived in 1941 and departed in 1947. An article by Charles in the Canadian Journal of Economics and Political Science, 1941, 7(3):447-477, gives her location as Ottawa. In an acknowledgement, Charles thanks Coats and DBS staff for their cooperation and research facilities. It is possible that she became a bureau employee only in 1942 (Worton, 1990). This is yet to be verified.

8. Nathan Keyfitz is listed in the same years in these calendars as giving courses in Statistics and Statistical Services. These were probably given in the evening.

9. It is reported by colleagues and students in Canada and abroad that Charies was difficult and not popular. A former student, co-worker and admirer of both Charles and Hogben has said that although Charles was "....a very kind, helpful, scholarly guru....she was quite unable to make friends as $\mathrm{L}$ (ancelot) $\mathrm{H}$ (ogben) did, and this was her achilles heel". (Taylor, 1991). Another demographer of the same generation notes, with much restraint, that Charles and Hogben "....had the reputation of being somewhat prickly...." (Grebenik, 1991). In Charles' case, it was her appearance of formidable self confidence that apparently was very "off-putting", particularly to men.

10. This presentation is taken largely from the obituary by Duff Spafford, 1977 .

11. Unfortunately Kasahara had left no written record of the verbal instructions she had given bureau computer programmers for processing the 1961 Census data on fertility, nuptiality and migration. It took considerable time, effort and persistence to track down and document the details of the computer treatment of the 1961 demographic data after Kasahara's passing. Although this peculiar situation caused some speculation and comment, it is clear that Kasahara made important and lasting contributions to Canadian demography.

12. The subject of Canadians who were obliged and encouraged in this period to pursue studies and careers abroad is explored and examined in greater detail in "Demography in Canada" (forthcoming).

\section{References}

Allingham, J.D. 1967. The demographic background to the change in the number and composition of female wage earners in Canada, 1951-1961. Special labour force studies. Series B. No. 1. Ottawa, ON: Dominion Bureau of Statistics. 
Allingham, J.D., and B. Spencer. 1968. Women who work. Part 2 Special labour force studies. Series B. No. 2. Ottawa, ON: Dominion Bureau of Statistics.

Anderson, I.B. 1966. Internal migration in Canada. Staff study No. 13. Ottawa, ON: Economic Council of Canada.

1991. Answers to a personal questionnaire, and letter 27/08/91.

Archibald, K. 1970. Sex and the Public Service. Ottawa, ON: Queen's Printer.

Baudry, Y. 1938. The circumstances of accidental death in Canada in 1936. Canadian Public Health Journal 29(10):127-130.

Buckley, K. 1962. Historical estimates of internal migration in Canada. Papers. CPSA Conference on Statistics, 1960. Toronto, ON: University of Toronto Press.

Canada. 1945. Administrative Report of the Dominion Statistician. 1941 Census of Canada. Ottawa, ON: King's Printer.

Canada: 1959. Equal Pay for Equal Work: the Growth of the Idea in Canada. Department of Labour, Women's Bureau. Ottawa, ON: Queen's Printer.

Canada. 1964a. Women at Work in Canada. Ottawa, ON: Department of Labour.

Canada. 1964b. Age and sex composition, 1961 Census of Canada. Bulletin 7. 1-4, Cat. 99-514. Ottawa, ON: Dominion Bureau of Statistics.

Canada. 1968. Fertility trends in Canada. 1961 Census of Canada. Bulletin 7. 2-2, Cat. 99 527. Ottawa, ON: Dominion Bureau of Statistics.

Canada. 1970. Introduction to Volume IV 1961 Census of Canada. Bulletin 4. 1-11. Cat. $98-$ 511. Ottawa, ON: Dominion Bureau of Statistics.

Canada. 1987. Population Estimation Methods, Canada. Catalogue 91-528E. Ottawa, ON: Statistics Canada.

Casgrain, T. 1973. A Woman in a Man's World. Toronto, ON: Maclelland and Stewart.

Charles, E. 1934. The Twilight of Parenthood. A Biological Study of the Decline of Population Growth. London, England: Watts and Company. . 1939. Who's Who. London, England.

. 1948. The Changing Size of the Family in Canada. 1941 Census of Canada Census Monograph No. 1. Ottawa, ON: King's Printer.

Fleming, M. 1967. Births, Deaths and Immigration on a Census Year Basis for Canada and the Provinces. 1921- (immigration 1931-) 1966. Ottawa, ON: Dominion Bureau of Statistics.

Fleming, M. and D. Nagnur: 1970. Refinements in the Techniques used for Estimating Interprovincial Migration: An Assessment. Ottawa, ON: Dominion Bureau of Statistics. 
Friedan, B. 1963. The Feminine Mystique. New York, NY: Dell.

George, M.V. 1967. Review of Canada's recent national population projections. In Technical memorandum (PEP series) No. 1. Ottawa, ON: Dominion Bureau of Statistics.

. 1970. Internal Migration in Canada. Demographic Analyses. A 1961 Census Monograph. Ottawa, ON: Dominion Bureau of Statistics.

Goldberg, S. 1967. Yoshiko Kasahara, 1912-1966. The Canadian Journal of Economics and Political Science 33:459-460.

. 1984. Personal letter 15/04/84.

Grebenik, E. 1959. The Development of Demography in Great Britain. In The Study of Population. An Inventory and Appraisal. Chicago, IL: The University of Chicago Press. . 1986. Demographic research in Britain, 1936-1986. Paper presented at the conference, Population Research in Britain, University of East Anglia. . 1991. Personal letter 12/04/91.

Hauser, P. and O.D. Duncan. 1959. The Study of Population.. An Inventory and Appraisal. Chicago, IL: The University of Chicago Press.

Johnson, M.D. 1971. History of the Status of Women in the province of Quebec. Cultural Tradition and Political History of Women in Canada. Royal Commission on the Status of Women in Canada. Ottawa, ON: Information Canada.

Judek, S. 1968. Women in the Public Service: Their Utilization and Employment. Department of Labour. Ottawa, ON: Queen's Printer.

Kasahara, Y. and A.H. Le Neveu. 1958. Demographic trends in Canada, 1941-1956. Canadian Journal of Economics and Political Science 24:9-20.

Kasahara, Y. 1963. The Flow of migration among the provinces of Canada, 1951-1961. CPSA 1961 Conference on Statistics. Papers. W.C. Hood and J.A. Sawyer (eds). Toronto, ON: University of Toronto Press.

Quarterly:70(3):303-313.

1963. A profile of Canada's metropolitan centres. Queen's

Kasahara, Y., F.T. Denton and S. Ostry, 1964. Population and labour force Projections to 1970. Staff Study No. 1. Ottawa, ON: Economic Council of Canada.

1965. Partial programme for population projections. Ottawa, ON: Dominion Bureau of Statistics.

- 1965. Internal Migration and the Family Life Cycle: Canadian Experience over the 1956-1961 Period. Belgrade, Yugoslavia. United Nations World Population Conference.

1966. Mobility of Canada's Population, 1956-1961. In Canada Year Book, 1966. Ottawa, ON: Queen's Printer. 
57(2):55-59. 1966. Population trends in Canada. Canadian Journal of Public. Health

Keyfitz, N. 1950. The growth of Canadian population. London, England. Population Studies $4(1): 47-63$. $17 / 12 / 90$.

1984, 1990. Personal conversations. Ottawa, ON: Statistics Canada, 11/03/84;

. 1988, 1989. Informal talk to students 03/06/88. Personal conversation 02/06/89. Ottawa, ON: Statistics Canada.

Krotki, KJ., and E. Lapiexre. 1968. La fécondité au Canada selon la religion, l'origine ethnique et l'état matrimonial. Population (23)(4):815-834.

Kuczynski, R.R. 1930. Birth Registration and Birth Statistics in Canada. Washington, DC: The Brookings Institution.

Langlois, G. 1934. Histoire de la population canadienne-française. Montreal, PQ: Alberta Levesque.

Lapierre, E. 1969a. Les variations de la fécondité dans la région de Montréal. MA thesis. Montreal, PQ: Department of Demography, University of Montreal.

. 1969b. Recommendations for data on childspacing for the 1971 Census. Working paper (Census Planning and Procedure Series) No. 3E. Ottawa, ON: Dominion Bureau of Statistics.

1970. Estimation of Net Census Underenumeration by Age and Sex, Using Demographic Analysis. Demographic Analysis and Research Section. Ottawa, ON: Dominion Bureau of Statistics.

Légaré, J. 1969. Les religieuses du Canada: leur évolution numérique entre 1965 et 1980. Recherches sociographiques 10(1):7-21.

LeNeveu, A. and M. Fleming, 1965. Official Estimates of Population. Census Technical Paper No. 2. Ottawa, ON: Dominion Bureau of Statistics.

Levitt, K. 1960. Population Movements in the Atlantic Provinces. Commissioned by Atlantic Provinces Research Board. Prepared by Atlantic Provinces Economic Council (APEC).

1963. Population Migration in the Atlantic Provinces. CPSA Conference on statistics, 1961. Papers. Wm. C. Hood and John A. Sawyer (eds). Toronto, ON: University of Toronto Press.

1991. Personal letter and answers to a personal questionnaire, 28/01/91.

Lorimer, F. 1959. The Development of Demography. In The Study of Population. An Inventory and Appraisal. Chicago, IL: The University of Chicago Press.

.Macleod, B. 1949 (Robinson, Betty Belle, 1949). Bibliography of Population and Immigration with Special Reference to Canada. Economics Research Laboratory. Hamilton, ON: McMaster University. 
1957. International measures for training in demography. Proceedings of the World Population Conference. Belgrade, Yugoslavia. Vol. III. New York, NY:United Nations.

1958. Economic growth and migration to and from British North America During the 18th and 19th centuries. Dominion Bureau of Statistics. Paper presented at 1958 meetings of the Population Association of America.

. 1969. Enrolments, fertility and migration in Ontario. Department of Educational Planning. Ontario Institute for Studies in Education. Toronto, ON: Informal paper No. 9.

(ed.) 1970. Demography and educational planning. Proceedings from a conference on the implications of demographic factors for educational planning and research. Toronto, ON: Ontario Institute for Studies in Education.

1988, 1991. Personal conversation, Ottawa, ON 08/07/88. Personal letters $24 / 06 / 91 ; 21 / 06 / 92$.

Macleod, B., C. Ivison and N. Bidani. 1972. Patterns and trends in Ontario population. An Ontario Population Report. Toronto, ON: Ontario Institute for Studies in Education.

McDonald, L. and M.S. Lenglet 1973. The status of women at McMaster University. In Women in Canada. Marylee Stephenson (ed.) Toronto, ON: New Press.

Nagnur, D. and M.E. Fleming. 1969. A Note on the population estimation procedure. Population estimates and projections series working paper no. 1. Census Division. Ottawa, ON: Dominion Bureau of Statistics.

Ostry, S. 1968. The Female Worker in Canada. 1961 Census Monograph. Cat. 99-553. Ottawa, ON: Dominion Bureau of Statistics.

Ostry; S. and J. Podoluk. 1966. The Economic Status of the Aging. Ottawa, ON: Dominion Bureau of Statistics.

Robson, R.A.H., and M. Lapointe. 1971. A Comparison of Men's and Women's Salaries and Employment Fringe Benefits in the Academic Profession. Prepared for the Canadian Association of University Teachers. The Royal Commission on the Status of Women in Canada. Ottawa, ON: Information Canada.

Rocher, G. 1962. Les modèles et le statut de la femme canadienne-française. Revue Internationale des Sciences Sociales. UNESCO, Paris, France. Vol. 14(1):132-139.

Rosenberg, L. 1939. Canada's Jews. A Social and Economic Study of the Jews in Canada. Montreal, PQ: The Canadian Jewish Congress.

Rossiter, M.W. 1976. Sexual segregation in the sciences: Some data and a model. In Harding and O'Barr (eds.), Sex and Scientific Inquiry. Chicago, IL: The University of Chicago Press. .

Ryder, N. 1988, 1991. Petsonal conversation and notes received. Ottawa, ON 18/11/88; personal letter, 22/05/91. 
Women in Demography in Canada: The 1940's to the Late 1960's

Salisbury, H. 1991. Answers to a personal questionnaire, 08/01/91; personal letter, 30/06/91.

Sametz, Z.W. 1990. Answers to a personal questionnaire and draft materials "Episodes at DBS/Statistics Canada", October, 1990; telephone conversation, 22/10/90.

Sheps, C. 1989, 1991. Answers to a personal questionnaire, 04/08/89; personal letter, $25 / 07 / 91$.

Sheps, M. and E. Lapierre-Adamcyk (eds.) 1972. On the Measurement of Human Fertility. Selected Writings of Louis Henry. New York, NY: Elsevier Publishing Company.

Spafford, D. 1977. Obituary, Mabel Timlin. Canadian Journal of Economics 10(2):279-281.

Stoddart, J. 1973. The woman suffrage bill in Quebec. Public opinion as reflected in the press. In Marylee Stephenson (ed.), Women in Canada. Toronto, ON: New Press.

Stone, L.O. 1969. Migration in Canada. Regional Aspects. A 1961 Census monograph. Ottawa, ON: Dominion Bureau of Statistics.

Stone, M. and G. Kokich. 1966. A Bibliography of Canadian Demography. Ottawa, ON: Dominion Bureau of Statistics.

Taylor, W. 1991. Personal letter, 22/05/91.

Timlin, M. 1951. Does Canada Need More People? Toronto, ON: Oxford University Press.

Wargon, S.T. 1967a. Reconciliation and adjustment of the 1961 Census fertility sample data. Technical Memorandum General Series no. 16. Ottawa, ON: Dominion Bureau of Statistics.

. 1967b. Canadian census data on fertility, Census Technical Memorandum no. 17 (General Series). Ottawa, ON: Dominion Bureau of Statistics.

1968. Reconciliation and adjustment of the 1961 Census migration sample data. Census Technical Memorandum no. 22 (General Series). Ottawa, ON: Dominion Bureau of Statistics.

Worton, D. 1990. Draft chapters. History of Statistics Canada Project. Ottawa, ON: Statistics Canada.

Wrong, D.H. 1974, 1991. Personal letters, 18/09/74; 23/10/91.

Received October, 1991; revised July, 1992. 
